\title{
Reappraisal of Rasmussen's syndrome with special emphasis on treatment with high doses of steroids
}

\author{
D Chinchilla, O Dulac, O Robain, P Plouin, G Ponsot, J F Pinel, D Graber
}

\begin{abstract}
Eight patients with Rasmussen's syndrome and epilepsia partialis continua were treated with high doses of steroids, including pulses of methylprednisolone and prednisone in decreasing doses. Three patients exhibited clinical, radiological, or histological evidence of bilateral involvement. Epilepsy and focal deficit decreased within six months in seven patients. Only five patients, in whom steroid treatment had begun less than 15 months after the onset of epilepsia partialis continua, experienced a lasting effect although they had periodic episodes of transient relapse. Treatment with high doses of steroids seems advisable during the first year after onset of epilepsia partialis continua, before hemiplegia has developed and in cases with bilateral involvement.
\end{abstract}

(F Neurol Neurosurg Psychiatry 1994;57:1325-1333)

In 1958 Rasmussen reported three patients with intractable focal seizures, a slowly progressive neurological deterioration, progressive focal, mainly perisylvian, cortical atrophy, and a mild inflammatory process including perivascular cuffs of round cells, microglial nodules, and mild meningitis. ${ }^{1}$ Since then, several cases with the same findings have been reported..$^{2-9}$ About half of the patients showed epilepsia partialis continua at some time. ${ }^{10}$ These patients have characteristic clinical and EEG abnormalities consisting of multiple independent foci and frequent EEG discharges, usually without clinical correlation, that persist during sleep. ${ }^{67}$ This suggests that there is a wide epileptogenic zone comprising several independent foci as shown by corticography. ${ }^{11}$

To date, no antiepileptic drug has proved to be effective in controlling the disease or in stopping its progression. ${ }^{12}$ Focal excision and callosotomy were unsatisfactory in many cases. ${ }^{91314}$ Multiple subpial transection has been used but without lasting results. ${ }^{15}$ Only hemispherectomy seems to be useful to control seizures and improve the functional state of the patients. ${ }^{16}$ This procedure is appropriate, however, only in patients with hemiplegia.

Preliminary reports show that immunoglobulins ${ }^{17}$ or high doses of steroids ${ }^{18}$ may be useful in some patients at an early stage of the disease. We studied patients with
Rasmussen's syndrome who had epilepsia partialis continua and who received steroids as part of their treatment.

\section{Methods}

The diagnosis of epilepsia partialis continua was based on the presence of localised, nearly continuous, or permanent myoclonic jerks persisting during sleep combined with abnormal and asymmetric EEG background activity, multiple independent foci, and frequent EEG or clinical discharges, ${ }^{67}$ usually lacking electroclinical correlation.

Subacute focal encephalitis was suspected as the cause of epilepsy if at least one of the following criteria was fulfilled: (a) a progressive neurological deficit at the beginning or after onset of epilepsia partialis continua; (b) progressive hemispheric atrophy on CT or MRI, whether associated with density or signal abnormalities or not; $(c)$ oligoclonal proteins on electrophoresis of CSF; (d) inflammatory appearance of a cerebral biopsy.

We reviewed eight patients referred to the Hopital Saint Vincent de Paul in Paris since 1983 who were treated with high doses of steroids. For all patients, family and perinatal history, events preceding the first seizure, age of onset and type of first seizure, age of onset of epilepsia partialis continua, and repeat neurological examinations were analysed and EEG, CT and MRI, CSF investigations, and histological specimens were reviewed.

The files were studied retrospectively with particular emphasis given to: (a) the progression of epilepsia partialis continua; $(b)$ the time lag between the onset of the first seizure and onset of epilepsia partialis continua and neurological deficit to initiation of steroid treatment; $(c)$ steroid treatment schedule; $(d)$ the evolution of epilepsia partialis continua, considering its extension to the upper or lower limb, or face; (e) the evolution of neurological deficits, considering persistence or recovery of lost abilities, especially motor activities, particularly walking, and speech; $(f)$ the course of radiological abnormalities and abnormalities on CSF protein electrophoresis during steroid treatment; $(g)$ histological findings. Four patients of this series have been reported in a preliminary study. ${ }^{18}$

\section{Results}

CHARACTERISTICS OF PATIENTS (TABLES 1 AND 2)

Eight patients (six girls, two boys) fulfilled at 
Table 1 Age of onset (y) and topography (unilateral or bilateral) of seizures, epilepsia partialis continua and motor deficit, radiological, and CSF findings

\begin{tabular}{|c|c|c|c|c|c|c|c|c|}
\hline \multirow[b]{2}{*}{ Patients } & \multirow{2}{*}{$\frac{\text { Seizures }}{\text { Age of onset }}$} & \multicolumn{2}{|c|}{ Epilepsia partialis continua } & \multicolumn{2}{|l|}{ Motor deficit } & \multirow{2}{*}{$\begin{array}{l}\text { CT or MRI } \\
\text { Hemispheric } \\
\text { atrophy }\end{array}$} & \multirow[b]{2}{*}{ Density/signal } & \multirow{2}{*}{$\begin{array}{l}\text { CSF } \\
\text { oligoclonal band }\end{array}$} \\
\hline & & Age of onset & Topography & Age of onset & Topography & & & \\
\hline $\begin{array}{l}1 \\
2 \\
3 \\
4 \\
5 \\
6 \\
7 \\
8\end{array}$ & $\begin{array}{c}3 \cdot 25 \\
3 \cdot 16 \\
5.9 \\
14 \\
6 \cdot 16 \\
4 \cdot 25 \\
3.5 \\
8 \cdot 75\end{array}$ & $\begin{array}{r}5 \\
3 \cdot 6 \\
6 \cdot 4 \\
13 \cdot 4 \\
7 \cdot 9 \\
11 \cdot 6 \\
4 \cdot 1 \\
9\end{array}$ & $\begin{array}{l}\text { Uni } \\
\text { Uni } \\
\mathrm{Bi} \\
\text { Uni } \\
\text { Uni } \\
\text { Uni } \\
\mathbf{B i} \\
\mathbf{B i}\end{array}$ & $\begin{array}{c}5 \cdot 25 \\
3 \cdot 6 \\
7 \\
14 \\
8 \cdot 25 \\
11 \cdot 6 \\
4 \cdot 16 \\
8 \cdot 75\end{array}$ & $\begin{array}{l}\text { Uni } \\
\text { Uni } \\
\text { Bi } \\
\text { Uni } \\
\text { Uni } \\
\text { Uni } \\
\text { Uni } \\
\text { Uni }\end{array}$ & $\begin{array}{l}+ \\
+ \\
+ \\
+ \\
+ \\
+ \\
+ \\
+\end{array}$ & $\begin{array}{l}- \\
- \\
+ \\
+ \\
+ \\
+ \\
+ \\
+ \\
+\end{array}$ & $\begin{array}{l}- \\
- \\
+ \\
- \\
+ \\
- \\
+ \\
+\end{array}$ \\
\hline
\end{tabular}

Uni = Unilateral; bi $=$ bilateral.

Table 2 Evolution of epilepsia partialis continua and main neurological deficit with regard to steroid treatment

\begin{tabular}{|c|c|c|c|c|c|c|c|}
\hline \multirow[b]{2}{*}{ Patients } & \multicolumn{2}{|c|}{ Fust before treatment } & \multicolumn{2}{|l|}{ Initial response } & \multicolumn{2}{|l|}{ Long term evolution } & \multirow{2}{*}{$\begin{array}{l}\text { Follow } \\
\text { up } \\
\text { (months) }\end{array}$} \\
\hline & $E P C$ & Deficit & $E P C$ & Deficit & $E P C$ & Deficit & \\
\hline 1 & $\mathbf{R H}$ & $\begin{array}{l}\text { Motor RH } \\
\text { Does not walk }\end{array}$ & $\begin{array}{l}\text { Less extensive: } \\
4 \text { months (RU) }\end{array}$ & $\begin{array}{l}\text { Motor RH } \\
\text { Walks with assistance: } \\
5 \text { months }\end{array}$ & $\begin{array}{l}\text { Persistent } \\
\text { (RU) }\end{array}$ & $\begin{array}{l}\text { Progressive }(\mathrm{RH}) \\
\text { Hemiplegia since } \\
23 \text { months }\end{array}$ & 48 \\
\hline 2 & $L$ foot & $\begin{array}{l}\text { Motor LLo } \\
\text { Walks with assistance }\end{array}$ & $\begin{array}{l}\text { Remission: } 1 \\
\text { month }\end{array}$ & $\begin{array}{l}\text { Motor recovery: } 5 \text { months } \\
\text { Walks independently: } \\
5 \text { months }\end{array}$ & $\begin{array}{l}\text { Periodic relapse } \\
\text { with fever (LULo) }\end{array}$ & $\begin{array}{l}\text { Periodic appearance } \\
\text { with fever (LLo) }\end{array}$ & 33 \\
\hline 3 & RLo & $\begin{array}{l}\text { Motor RLo + LLo } \\
\text { Does not walk }\end{array}$ & $\begin{array}{l}\text { Less extensive: } \\
1 \text { month (RFo) }\end{array}$ & $\begin{array}{l}\text { Motor RLo: } 3 \text { months } \\
\text { Walks independently: } \\
3 \text { months }\end{array}$ & $\begin{array}{l}\text { Periodic relapse } \\
\text { every } 3-4 \text { months for } \\
4 \text { weeks (R or } L L o)\end{array}$ & $\begin{array}{l}\text { Periodic increase every } \\
3-4 \text { months for } 4 \text { weeks } \\
\text { (R or LLo) } \\
\text { Walks with assistance }\end{array}$ & 36 \\
\hline 4 & RU + RLo & $\begin{array}{l}\text { Motor RLo } \\
\text { Sensory RU } \\
\text { Walks with assistance }\end{array}$ & $\begin{array}{l}\text { Remission: } 1 \\
\text { month }\end{array}$ & $\begin{array}{l}\text { Motor recovery: } 4 \text { months } \\
\text { Walks independently: } \\
1 \text { month }\end{array}$ & $\begin{array}{l}\text { Rare myoclonic jerks } \\
\text { every mornings (RU) } \\
\text { since } 2 \text { months }\end{array}$ & $\begin{array}{l}\text { Sensory RU } \\
\text { No motor deficit }\end{array}$ & 23 \\
\hline 5 & RH & $\begin{array}{l}\text { Motor RH } \\
\text { Does not walk }\end{array}$ & $\begin{array}{l}\text { Remission: } 7 \\
\text { months }\end{array}$ & $\begin{array}{l}\text { Motor RU: } 3 \text { months } \\
\text { Walks independently: } \\
3 \text { months }\end{array}$ & $\begin{array}{l}\text { Periodic relapse } \\
\text { every } 2-3 \text { months } \\
\text { (RH) }\end{array}$ & $\begin{array}{l}\text { Progressive after each } \\
\text { relapse (RH) } \\
\text { Hemiplegia since } \\
17 \text { months }\end{array}$ & 52 \\
\hline 6 & $\begin{array}{l}\text { Lface }+ \\
\text { LU }\end{array}$ & $\begin{array}{l}\text { Motor LH } \\
\text { Walks with assistance }\end{array}$ & $\begin{array}{l}\text { Remission: } 3 \\
\text { months }\end{array}$ & $\begin{array}{l}\text { Motor LH } \\
\text { Walks with assistance }\end{array}$ & $\begin{array}{l}\text { Periodic relapse } \\
\text { every } 3 \text { months for } \\
3-4 \text { weeks ( } L \text { face }+ \\
\text { LU) }\end{array}$ & $\begin{array}{l}\text { Walks independently: } \\
\text { Periodic increase every } \\
3 \text { months for 3-4 weeks } \\
\text { (does not walk) }\end{array}$ & 50 \\
\hline 7 & LH & $\begin{array}{l}\text { Motor LH } \\
\text { Bedridden }\end{array}$ & $\begin{array}{l}\text { Less extensive: } \\
2 \text { months } \\
\text { (LU + LLo) }\end{array}$ & $\begin{array}{l}\text { Motor LH } \\
\text { Bedridden }\end{array}$ & $\begin{array}{l}\text { Persistent } \\
\text { (LU + Lo) }\end{array}$ & $\begin{array}{l}\text { Motor LH } \\
\text { Bedridden }\end{array}$ & 12 \\
\hline 8 & $\mathbf{R U}$ & $\begin{array}{l}\text { Motor RU + Rface } \\
\text { Aphasia }\end{array}$ & $\begin{array}{l}\text { Remission: } 18 \\
\text { months }\end{array}$ & $\begin{array}{l}\text { Motor RU: } 18 \text { months } \\
\text { Aphasia improvement: } \\
18 \text { months }\end{array}$ & $\begin{array}{l}\text { Relapse RU: } \\
24 \text { months } \\
\text { Remission: } \\
33 \text { months }\end{array}$ & $\begin{array}{l}\text { Aphasia relapse: } 24 \text { months } \\
\text { Aphasia improvement: } \\
33 \text { months } \\
\text { Motor } R \text { face }+\mathrm{U}: \\
24 \text { months } \\
\text { Motor RU: } 33 \text { months }\end{array}$ & 81 \\
\hline
\end{tabular}

EPC = Epilepsia partialis continua; $\mathrm{L}=$ left; $\mathrm{R}=$ right; $\mathrm{H}=$ half of the body; $\mathrm{Lo}=$ lower limb; $\mathrm{U}=$ upper limb.

least one of the criteria of Rasmussen's syndrome (table 1) and were treated with high doses of steroids as part of their treatment.

None of them had a relevant perinatal history and only one had a neurological deficit (congenital peripheral facial palsy) before the onset of the disease. Three patients had a family history of epilepsy or febrile seizures. Both grandfathers of one patient were half brothers. A febrile disease of unidentified aetiology preceded the beginning of the disease in two instances.

Epilepsy was the first manifestation of the disease in all patients. It appeared between the ages of 3 years and 2 months and 13 years and 5 months (table 1). First seizures were brief in most cases, and they were simple partial in five patients and complex partial in two. In the other patient, epilepsia partialis continua was misdiagnosed for seven months as tremor of the right upper limb, until a secondary generalised seizure followed by focal motor deficit occurred (patient 4).
Epilepsia partialis continua began between 3 years and 8 months and 13 years and 5 months (table 1). It involved the right side in three patients, the left side in two, and both sides simultaneously or alternately in three (table 2). At the onset of steroid treatment, epilepsia partialis continua involved either the upper or the lower limb in three patients, the face and the upper limb, and the upper and lower limbs in one patient each (table 2). In the other three patients it involved the whole of one side of the body.

All eight patients exhibited a focal motor deficit (table 2). It was never the first manifestation of the disease, and appeared three months before epilepsia partialis continua in one patient. It was unilateral in seven and bilateral in one; a sensory deficit preceded the motor deficit in one case. The age at which the motor deficit was first noted ranged from 3 years and 8 months to 14 years (table 1 ). At the start of steroid treatment seven patients were unable to walk independently; three of 
Figure $1 \quad T 2$ weighted MRI of brain of patient 7 showing bilateral hyperintense signal abnormalities in white matter (arrows).

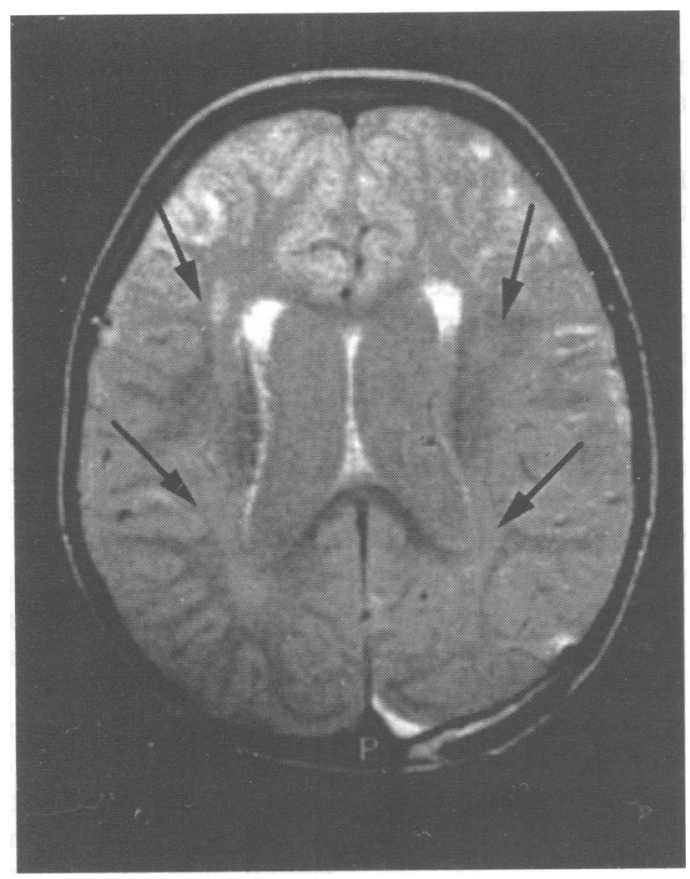

them could still walk with assistance. Patients also exhibited sensory (three), visual (one), or phasic (four) deficits.

Computed tomography or MRI before starting steroids disclosed cortical atrophy in seven patients and density or signal abnormalities in six. In two cases there were bilateral abnormalities of CT density and MRI signal (fig 1, table 1). Electrophoresis of CSF protein was monoclonal in four patients, but no specific antibody could be identified (table 1 ).

Two patients underwent cerebral biopsy before steroid treatment. Histological examination showed typical inflammatory features of Rasmussen's syndrome consisting of meningitis, perivascular lymphocytic cuffing, microglial nodules, and diffuse astrocytosis (table 3). Figure 2 illustrates a pronounced meningoencephalitic process including infiltration of the meninges by round cells and diffuse microgliosis within the cortex.

Four patients had received immunoglobulins, $a$-interferon, or both, six months to over three years before steroid treatment, without appreciable improvement.

There was bilateral involvement, clinically in three patients and radiologically in two. Bilateral involvement was confirmed at necropsy in one case. This patient died unexpectedly six years and nine months after the onset of steroid treatment and three years and seven months after it was stopped; her last seizure occurred 40 months before death and

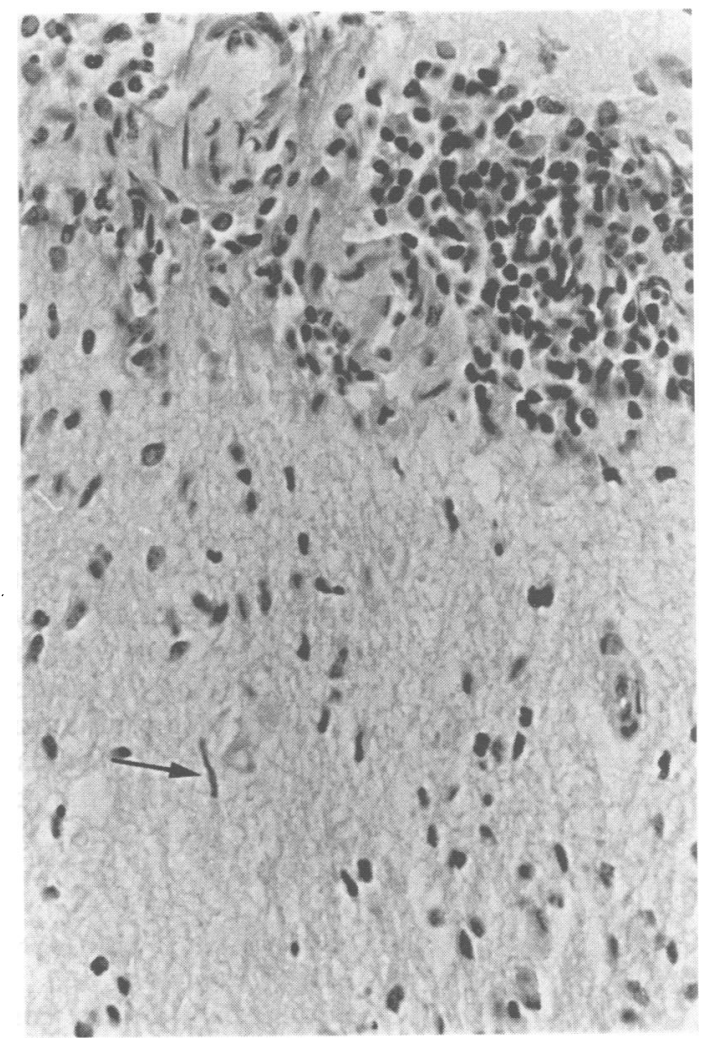

Figure 2 Occipital lobe biopsy of patient 7 showing meningitis with accumulation of round cells, neural depopulation within the cortex, and gliosis including many microglial cells sometimes elongated in "batonnets" (arrow). Haematoxylin eosin stain; magnification originally $\times 200$.

general necropsy showed only a right kidney cyst and mild liver steatosis.

\section{STEROID TREATMENT SCHEDULE AND SIDE} EFFECTS (TABLE 4)

Time lag from the onset of epilepsia partialis continua to steroid treatment ranged from two weeks to eight years, less than 15 months for five patients, and more than five years for three. The time lag after onset of a motor deficit was between one month and seven years and eight months (less than 15 months for five patients, more than four years for three). The treatment schedule was not the same for each patient, but all received the combination of three intravenous boluses of methylprednisolone $\left(400 \mathrm{mg} / \mathrm{m}^{2}\right.$ of body surface each) during the first six days (one every other day) and oral prednisone at $2 \mathrm{mg} / \mathrm{kg}$ of body weight daily.

The boluses were given during the first 12 months of treatment in six patients and for a longer period in the two others. A total of three to 18 boluses were given during the first 12 months (average 10). Two patients

Table 3 Histological findings

\begin{tabular}{llllllll}
\hline $\begin{array}{l}\text { Patients } \\
\text { (sample origin) }\end{array}$ & Meningitis & Perivascularitis & $\begin{array}{l}\text { Microglial } \\
\text { nodules }\end{array}$ & $\begin{array}{l}\text { Astrocytary } \\
\text { gliosis }\end{array}$ & $\begin{array}{l}\text { Diffuse } \\
\text { microgliosis }\end{array}$ & $\begin{array}{l}\text { Neuronal } \\
\text { destruction }\end{array}$ & $\begin{array}{l}\text { Perivascular } \\
\text { disintegration }\end{array}$ \\
\hline $\mathbf{1}$ (hemispherotomy) & 0 & + & 0 & + & 0 & + & + \\
5 (hemispherotomy) & 0 & + & + & + & + & + & + \\
6 (biopsy) & 0 & + & 0 & + & + & 0 & $?$ \\
7 (biopsy) & ++ & + & + & ++ & ++ & + & + \\
8 (necropsy) & 0 & + & 0 & 0 & 0 & + & + \\
\hline
\end{tabular}

$0=$ absent; $+=$ mild; $++=$ important; = non assessable. 
received three more boluses each, at 20 and 24 months of follow up respectively, for exacerbation of epilepsia partialis continua and neurological deficit.

Oral prednisone was given continuously at gradually decreasing dose over two to 26 months (average 18 months). It was reintroduced once in one patient and twice in another, for exacerbation of epilepsia partialis continua and neurological deficit.

Steroid related side effects occurred in all eight patients. In only one were they severe enough to need a decrease of the dose. Side effects consisted of Cushing's syndrome in eight, osteoporosis in three (one patient had a fracture of the femur two years after stopping steroid treatment), hypertension in one, and infection in one (oral and vaginal candida).

Transitory exacerbation of seizure frequency was found during the first week after the intravenous bolus series in two patients. Follow up after the start of steroid treatment ranged from 12 to 81 (average 42 ) months (table 2).

\section{RESULTS OF TREATMENT (TABLE 2)}

Initial response

Epilepsia partialis continua resolved in five patients, one to 18 months (average six months) after steroid treatment. For three patients, there was a decrease in extent of epilepsia partialis continua one, two, and four months after the start of steroid treatment. A change in motor deficit was seen in five patients: three improved and two experienced complete recovery. Improvement occurred three to 18 months after the start of treatment, and recovery after four and five months.

The series was divided according to the time lag from onset of epilepsia partialis continua to steroid treatment (table 1). It was 15 months or less for five patients. Epilepsia partialis continua resolved completely in four and its extension was decreased in one; two attained complete recovery of motor function after four and five months of treatment, one showed partial recovery after 18 months of treatment, and two remained unchanged. For the three patients with a time lag of over five years, epilepsia partialis continua resolved completely in one and the extent was decreased in two; two showed a decrease in their deficit three months later, and one remained unchanged. For the two patients whose motor deficit and epilepsia partialis continua resolved completely, the resolution of the motor deficit occurred after that of epilepsia partialis continua.

\section{Long term evolution}

The favourable response persisted in one patient who, during 23 months of follow up had rare myoclonic jerks every morning, without reappearance of the motor deficit.

Transitory relapse or increase of intensity and extent of epilepsia partialis continua and motor deficit was found in four patients. For three, relapse occurred periodically, every three to four months, and lasted three to four weeks. Two of these patients reverted to their previous state after each transient relapse, over 36 and 50 months of follow up respectively. The third one had an increase of motor deficit after each relapse of epilepsia partialis continua, over 36 months of follow up; at this point the patient underwent hemispherotomy, a procedure derived from functional hemispherectomy in which the hemisphere is only disconnected. ${ }^{19}$ The fourth patient showed unpredictable but rare periods of exacerbation, often in conjunction with a febrile illness, during the 33 months of follow up, always returning to the previous neurological condition. In all four patients with transitory exacerbations, these became progressively shorter and less frequent during the follow up period. One patient showed a single relapse lasting nine months before recovering to the previous neurological condition, over a follow up of 81 months.

Epilepsia partialis continua persisted after an initial limitation of its extent in two patients. In one of them, increasing motor deficit led to the patient undergoing hemispherotomy ${ }^{19} 47$ months after the onset of steroid treatment and 38 months after it was stopped because of lack of response. No surgical treatment was possible for the other patient because of bilateral involvement.

In regard to the time lag before initiation of steroid treatment, two of the three patients
Figure 3 (A) T2 weighted MRI of brain of patient 6 showing mild cortical atrophy and white matter hyperintense signal abnormalities in the right frontal lobe. (B) Four months later; MRI shows white matter hypersignal abnormalities with a clear abnormalities with a clear right frontal lobe. There was no significant change in cortical atrophy.
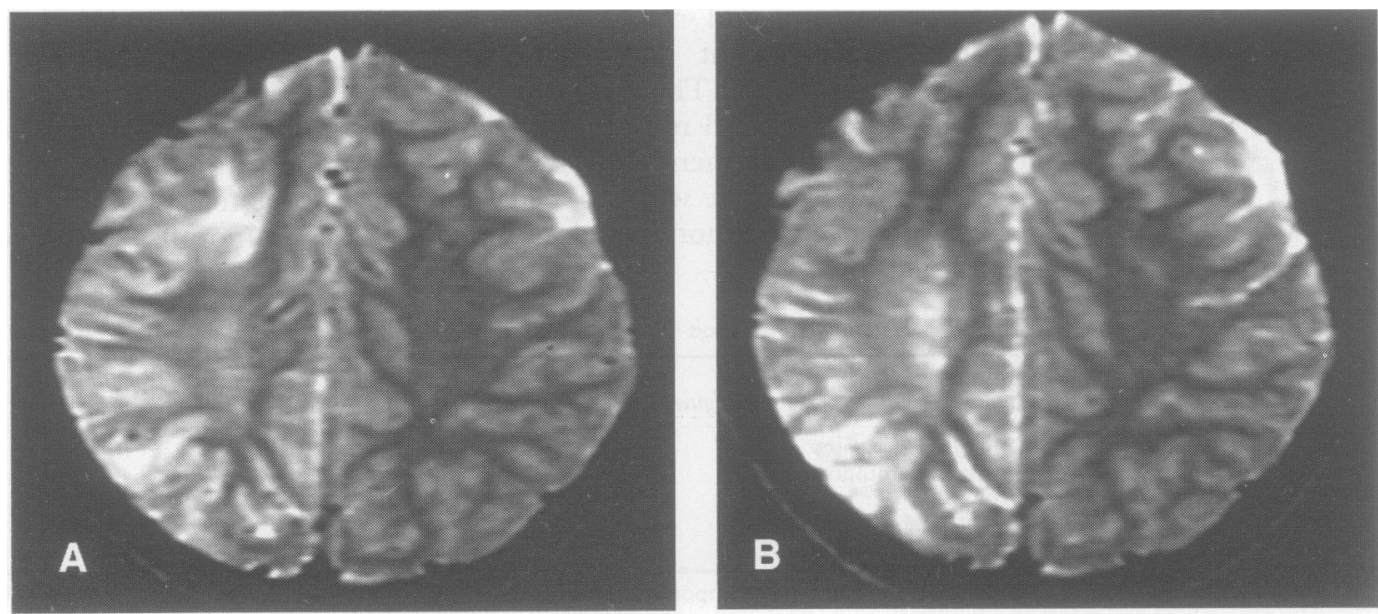
Table 4 Steroid treatment

\begin{tabular}{llcl}
\hline & $\begin{array}{l}\text { Time lag } \\
\text { EPC/steroids } \\
\text { (months) }\end{array}$ & $\begin{array}{l}\text { Total intravenous } \\
\text { pulse during } \\
\text { first 12 months }\end{array}$ & $\begin{array}{l}\text { Oral } \\
\text { prednisone } \\
\text { duration } \\
\text { (months) }\end{array}$ \\
\hline 1 & 70 & 8 & 9 \\
2 & 1 & 16 & 28 \\
3 & 60 & 14 & 26 \\
4 & 9 & 3 & 23 \\
5 & 96 & 18 & $2+13+18$ \\
6 & 15 & 6 & 32 \\
7 & 9 & 9 & 4 \\
8 & 0.5 & 5 & $23+8$ \\
\hline
\end{tabular}

with the latest start of steroid treatment underwent hemispherotomy because of persistent epilepsia partialis continua and fixed hemiplegia, and one had periodical but transitory episodes of exacerbation. Patients with a shorter time lag (two of five) showed a stable initial response with limited persistent epilepsia partialis continua in one of them, or transitory exacerbations of epilepsia partialis continua and motor deficit (three of five). Therefore, stable improvement was only found in patients treated within the first 15 months of the disease.

The monoclonal aspect of CSF protein electrophoresis persisted throughout follow up in two patients. It disappeared in one. No control was done for the last patient.

Evolution of hemispheric atrophy is difficult to assess because of the non-specific effects of steroids on the brain. It increased over the follow up period in three patients and appeared in the only patient in whom it was absent at the beginning of steroid treatment. In three patients it remained unchanged throughout the follow up.

The CT density or MRI signal abnormali-

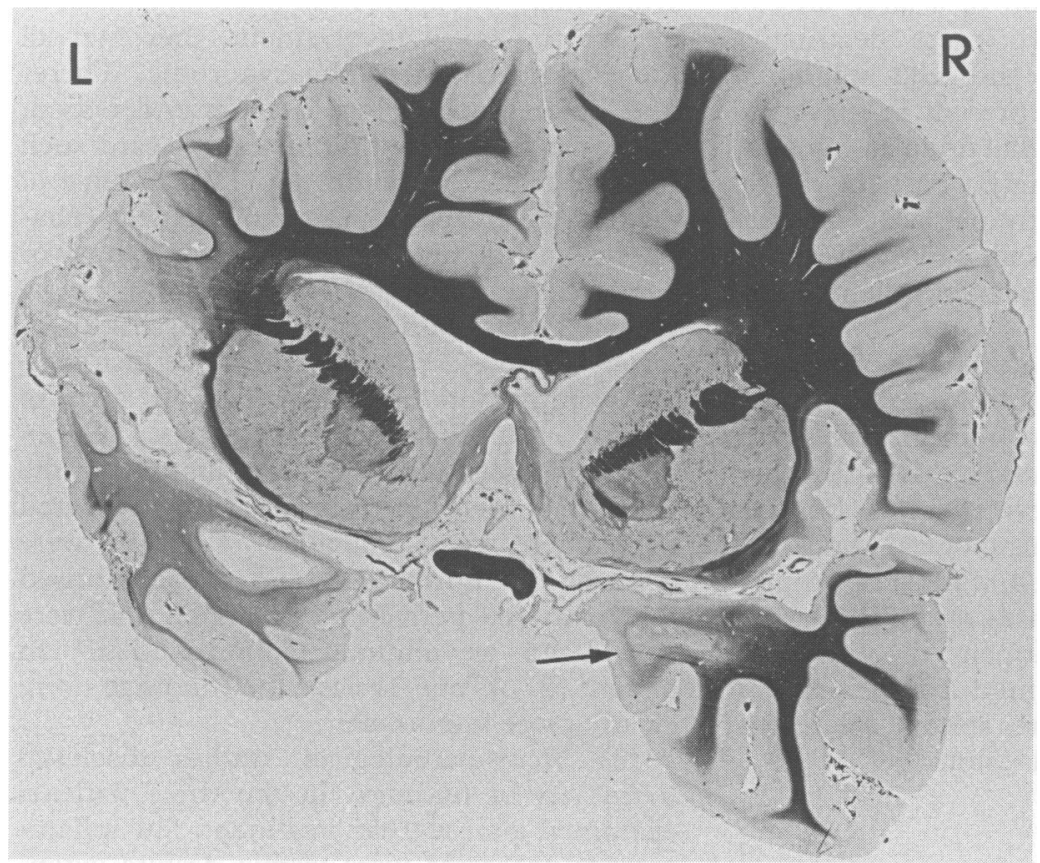

Figure 4 Necropsy of patient 8, showing left hemisphere atrophy including the frontal and temporal lobes. The internal part of the right temporal lobe includes segmental cortical lesions with pallor of the subcortical myelin (arrow). Woelke. stain; originally no magnification.

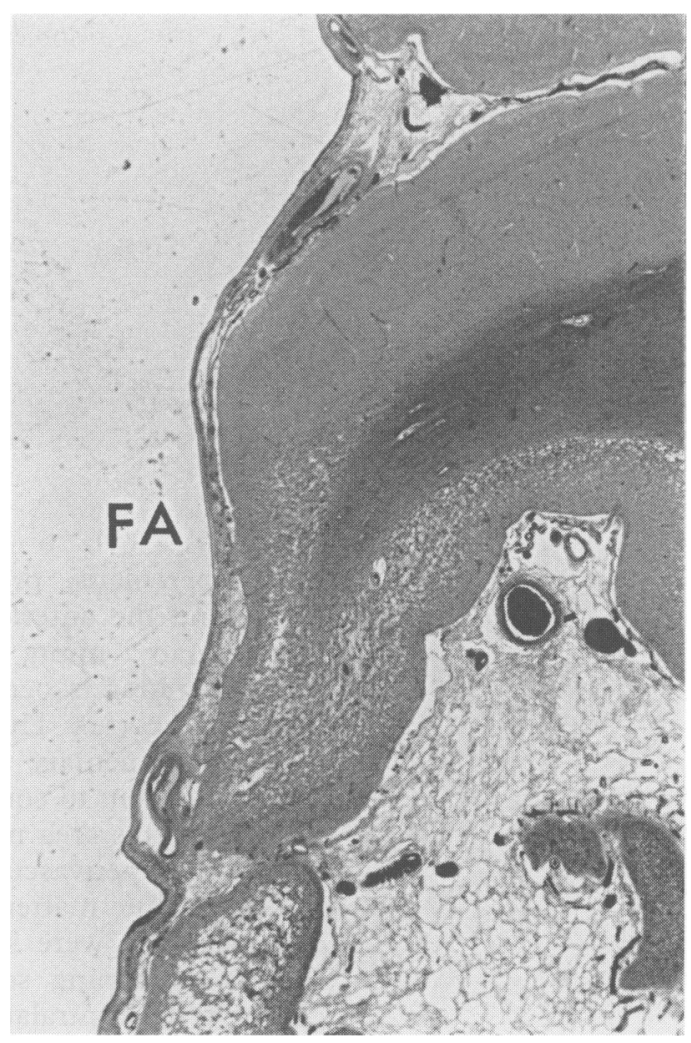

Figure 5 Necropsy of patient 8. Left frontal cortex showing the segmental cortical destruction without inflammation. Nissl stain; magnification originally $\times 20$.

ties diminished in two patients (fig 3), remained unchanged in three, and increased in one.

\section{Histological findings}

In three cases histological examination performed after extended steroid treatment disclosed only a slight inflammation process. Patient 8 examined six years and nine months after the start of steroid treatment and three years after it was stopped gives a good illustration of the lesions encountered. Necropsy performed 14 hours after death allowed extensive examination of the brain. Hemispheric lesions involved mainly the left side, which was severely atrophic (fig 4). The nerve cells had disappeared in the whole thickness of the cortex along a large portion of the cortical ribbon

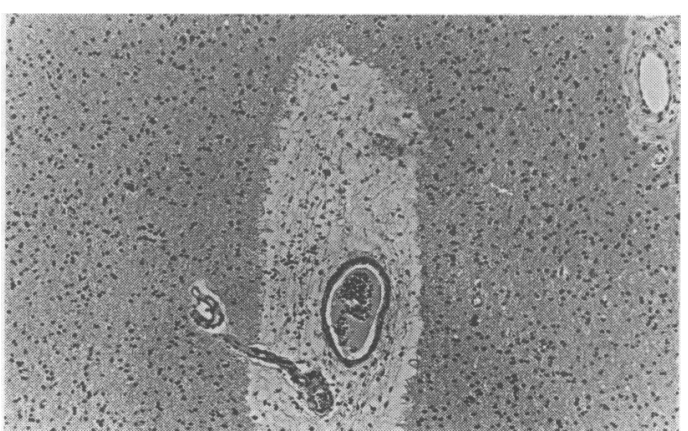

Figure 6 Necropsy of patient 8. White matter in the left semioval centrum showing perivascular myelin destruction without active inflammation. Luxol Nissl stain; magnification originally $\times 100$. 
Figure 7 Left hemispherotomy of patient 5. Frontal subcortical area 5. Frontal subcortical area a microglial nodule. Nissl stain; magnification originally $\times 200$

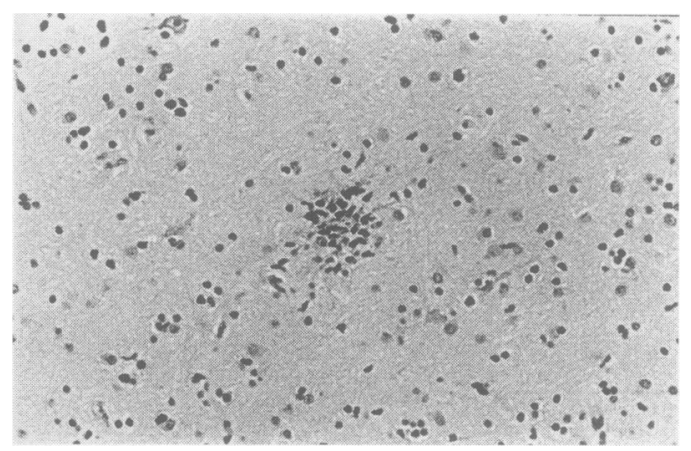

(pars opercularis, precentral gyrus, parietal gyrus, and the anterior part of the temporal lobe). Many empty vacuoles separated by astrocytic strands occupied the whole thickness of the cortex. The destruction of the cortex was segmentary and normal areas were closely adjacent to complete zones of necrosis (fig 5). In this area no microglial nodules or lymphocytic perivascular cuffs were visible. In the deep white matter several areas of myelin disappearance were seen around the vessels (fig 6) containing scarce elongated fibrous cells. On the contralateral side there were two types of lesion: firstly, some perivascular cuffing was present either in the white matter or in the cortex; secondly, some limited areas of neuronal depopulation were visible within the frontal cingular and temporal cortex. It must be emphasised that inflammatory signs had disappeared in the destroyed cortex occupying the major part of the left hemisphere. Mild inflammatory signs were visible only in discrete areas at the periphery of the lesion, in the portions of the cortex where no significant destruction was present.

In the two other cases also examined after protracted steroid treatment, hemispherotomy allowed examination of a large area of the brain. In these two cases destructive lesions were less intense and mild inflammatory processes were still present in preserved areas. Few typical microglial nodules were visible (fig 7). Interestingly, particularly in patient 5 , we found many perivascular areas of myelin disintegration with a loose fibrocytic meshwork without any residual inflammatory cells.

In summary, inflammatory signs were seen in all five brains examined histologically. They were bilateral in the only brain in which both sides were examined although this patient had exhibited no clinical evidence of bilateral involvement. Although histological abnormalities could not be followed, it must be emphasised that in the three cases examined several months after steroid treatment, the inflammatory process was very mild compared with patients examined before steroid treatment, despite extensive cortical lesions.

\section{Discussion}

In the present series, the diagnosis of Rasmussen's syndrome was based on clinical and EEG characteristics, including intractable focal seizures and progressive neurological deficit, and on direct or indirect evidence of progressive inflammatory disease of the brain. Only one patient did not exhibit inflammatory indices at the beginning, but the evolution confirmed the diagnosis.

We restricted the study to patients with epilepsia partialis continua although they comprise only half of the patients with Rasmussen's syndrome. ${ }^{10}$ This restriction avoided any uncertainty regarding diagnosis, as when excluding acute brain damage, subacute measles encephalitis, Alpers syndrome, MELAS disease, and various identifiable lesions in the Rolandic area, epilepsia partialis continua with progressive motor defect usually results from Rasmussen's syndrome. ${ }^{67}$ It also helped to improve the assessment of efficacy.

The pattern in our patients showed three particular characteristics previously not reported in detail in patients with Rasmussen's syndrome and epilepsia partialis continua.

(1) There were major fluctuations of epileptic manifestations and neurological deficit during follow up. Although occasionally mentioned in the literature, ${ }^{10}$ the tendency to relapse may have been overlooked in most previous series, as the disease is more severe with rapid destruction of large areas of the cortex when the treatment includes only conventional antiepileptic drugs.

(2) Three patients showed clear bilateral involvement. Motor deficit, epilepsia partialis continua, and radiological findings involved both sides in one, epilepsia partialis continua and radiological abnormalities were bilateral in another, and epilepsia partialis continua and neuropathological lesions were bilateral in the third. Some authors would object that these patients do not belong to Rasmussen's syndrome, ${ }^{20}$ but apart from bilateral clinical or neuropathological involvement, they met all the characteristics of the syndrome. Therefore, before the aetiology is better understood, only an operative definition can discard such patients from the syndrome. The absence of bilateral involvement in previous series probably reflects the neurosurgical origin (biopsy or hemispherectomy) of samples in most reported series rather than postmortem histological samples. ${ }^{92122}$ Only extensive histological examination at postmortem is able to detect multifocal abnormalities. Seven necropsy cases with full examination of the brain including microscopy of the spared hemisphere are available. ${ }^{821-23}$ Five were described as normal ${ }^{822} 23$ and two comprised thin scattered perivascular cuffs ${ }^{21} 22$ that were considered as minimal abnormalities. ${ }^{24}$ In patient 8 of our series, the findings were clearly more important.

(3) Neuropathological studies disclosed three sets of findings. In the three patients examined after steroid treatment, few inflammatory processes were visible despite extensive necrosis of the cortex. Numerous areas of perivascular demyelination were present in the white matter of two brains. In one case, 
necropsy allowed examination of both hemispheres and showed that perivascular involvement was bilateral, as previously described by Gupta et al..$^{21}$ There was a striking graduation of the lesions: areas of complete necrosis of the cortex were completely devoid of inflammatory cells. By contrast, perivascular cuffs were found in zones of mild gliosis without complete necrosis.

Pathophysiology of Rasmussen's syndrome remains obscure. The first hypothesis of primary viral encephalitis already evoked by Rasmussen is supported by histological features including nodules of neuronophagia and predominant involvement of the grey matter. There is only limited supportive evidence: the Russian tick borne encephalitis, ${ }^{25}$ a viral disease, also produces epilepsia partialis continua. A positive cytomegalovirus in situ hybridisation has been reported in seven cases of Rasmussen syndrome ${ }^{26}$ and DNA probe hybridisation for Epstein-Barr virus in two cases. ${ }^{27}$ In two other cases association with acute uveitis during the early phase of chronic encephalitis raised the possibility of primary ocular viral infection. ${ }^{28}$

The possibility of a postinfectious disease mainly mediated by an immune process and developing after the disappearance of the triggering agent, is suggested by the presence of perivascular immunoglobulins in some cases $^{29}$ and by perivascular areas of myelin disintegration in the white matter in two cases of the present series.

Presumably epilepsy, which is particularly severe in Rasmussen's syndrome, plays a part to induce extensive cortical lesions and gradually involve the nearby cortex.

The disease has been repeatedly reported as refractory to all conventional antiepileptic drugs. ${ }^{12}$ At present, the only effective treatment is hemispherectomy. ${ }^{16}$ Such a procedure is inadvisable before hemiplegia has developed, or in patients who have bilateral involvement. In view of the pathophysiological hypotheses, it seems wise to reduce the inflammation with high doses of steroids, as for other inflammatory diseases of the CNS. ${ }^{30} 31$

The effects of steroids are difficult to assess based on the present open study. Although often self limited, however, the disease has rarely been reported to stabilise spontaneously. ${ }^{10}$ Some statements regarding the effect of steroids can be made. All patients had a positive initial response, even after late initiation of steroid treatment. The initial favourable response involved cessation of the extension of myoclonus, in others its disappearance. In other patients, disappearance of epilepsia partialis continua lasted several months, usually less than six months, but 18 months for one patient. The best and most lasting results were in patients in whom steroid treatment was initiated early, that is, less than 15 months after onset of epilepsia partialis continua or motor deficit. Follow up remains short in view of the protracted course of the disease. Histological studies showed no inflammatory cells in the demyelinated areas; this suggests the possibility of secondary dis- appearance of the inflammatory cuffs due to the long time lag from steroid treatment to histological examination.

Tolerance of treatment was good despite the high dose and prolonged schedule. The only reported data regarding tolerance of high dose steroid treatment involves adults mostly treated for multiple sclerosis and rheumatoid arthritis. Complications included infections, ${ }^{32-34}$ cardiac arrhythmia, ${ }^{35}{ }^{36}$ and avascular necrosis. ${ }^{37}$ One patient died suddenly. ${ }^{38}$ Most studies mention excellent tolerance ${ }^{3039}$ and no noticeable risk of osteonecrosis of the hip. ${ }^{40}$

The mode of action of steroids is difficult to determine. There are at least three possibilities: Firstly, steroid treatment may have an antiepileptic effect. Steroids are indeed powerful antiepileptic agents, ${ }^{41}$ particularly in generalised epilepsy. This effect is unlikely to be the major mode of action in Rasmussen's syndrome, however, for the following reasons: steroids may increase motor seizures. ${ }^{42-44}$ This was occasionally found in the present series during the first week after a bolus of methylprednisolone; an antiepileptic effect occurred mostly in the first two months of treatment, and usually in the first weeks. ${ }^{43}$ The time lag before decrease of epilepsia partialis continua was several months in this series.

Secondly, steroids may repair the blood brain barrier function ${ }^{45}$ and may have decreased the leakage of some substance originating from the serum and toxic to the brain. ${ }^{46}$ Indeed, seizures are known to decrease the effectiveness of the blood brain barrier, particularly if prolonged, a series, or status epilepticus ${ }^{45}$; this is likely to apply to patients with Rasmussen's syndrome. A decrease in permeability of the blood brain barrier has been shown in West syndrome treated with high doses of steroids ${ }^{47}$ and in multiple sclerosis monitored by means of serial gadolinium DTPA enhanced MRI. ${ }^{48}$ The decrease in size of the areas of MRI high intensity signal in two patients of the present series may be secondary to the improvement in blood brain barrier function produced by steroids.

Thirdly, steroids may have an anti-inflammatory effect. After several years of high dose steroids monoclonal bands on CSF protein electrophoresis disappeared in one patient and histological examination of the brain showed little inflammation although destructive lesions remained evident in three patients. Patient 8 illustrates the possibility of extensive cortical lesions associated with multiple perivascular demyelinated areas with only few perivascular inflammatory cuffs restricted to small areas, far from the extensive destructive lesions.

Some questions remain. Should a brain biopsy be performed before steroid treatment? Histological confirmation of the disease would ideally prevent diagnostic uncertainty. It would seem justified to indicate brain biopsy before such aggressive treatment as high doses of steroids. The decision to perform a biopsy is difficult to make as it should be performed 
early enough to initiate steroid treatment before major neurological deficit has taken place, at a stage where atrophy is restricted or has not even occurred. At this stage, a large biopsy sample in the involved Rolandic area cannot be taken without a high risk of worsening the clinical condition, and, the precise site of a valuable small biopsy is difficult to determine. Therefore the procedure may either be devastating or falsely negative. ${ }^{18}$ Even an open biopsy guided by simultaneous corticography may not avoid these risks.

Another question is how to give steroids? What are the respective indications for intravenous pulses and oral steroids? Because most patients have periodic exacerbation of the disease, repeat pulses given at regular intervals of one to three months in decreasing frequency could be the most appropriate answer. The value of combined oral steroids will also have to be determined. How long should steroid treatment be maintained before its initial effect is assessed? One year seems to be a minimum as epilepsia partialis continua often takes six months to resolve. When it is effective, three years of treatment may be necessary to prevent periodic relapses. Is it possible that some patients would benefit from other anti-inflammatory or immunosuppressive drugs?

Our series of cases shows that Rasmussen's syndrome includes several previously unreported characteristics-namely, bilateral neuropathological involvement and repeat episodes of worsening in the course of the disease. Steroids may be a promising treatment for patients with Rasmussen syndrome with epilepsia partialis continua when given in the first year of the disease, before hemiplegia has occurred, or in the case of bilateral involvement. The diagnosis needs to be made early, based on clinical, EEG, neurological, and CSF protein electrophoresis characteristics. Steroid treatment should be maintained for one year to assess its efficacy, and at least three years if effective. Steroid treatment should not, however, lead to delay or abandonment of hemispherectomy or modified hemispherectomy (in our case "hemispherotomy") if operation is indicated based on motor deficit. A prospective multicentre controlled study is needed to evaluate steroid treatment for Rasmussen's syndrome. In particular, immunoglobulins and intravenous boluses of steroids given at regular intervals from the early stage of the disease should be compared.

We are grateful to Professor Andermann and Professor Freeman for valuable remarks regarding the study and to Dr Huskin who reviewed the manuscript. The paper was presented in part at the American Epilepsy Society Meeting, Seattle, 9 December 1992.

1 Rasmussen T, Olszewski J, Lloyd-Smith D. Focal seizures due to chronic localized encephalitis. Neurology 1958; 8:435-45.

2 Aguilar MA, Rasmussen T. Role of encephalitis in the pathogenesis of epilepsy. Arch Neurol 1960;2:663-76.

3 Rasmussen T, McCann W. Clinical studies of patients with focal epilepsy due to "chronic encephalitis". Trans Am Neurol Ass 1968;93:89-94.
4 Gupta PC, Roy S, Tandon PN. Progressive epilepsy due to chronic persistent encephalitis. $\mathscr{F}$ Neurol Sci 1974;22 105-20.

5 Rasmussen T. Further observations on the syndrome of chronic encephalitis and epilepsy. Appl Neurophysiol 1978;41:1-12.

6 Dulac O, Dravet C, Plouin P, et al. Aspects nosologiques des épilepsies partielles continues chez l'enfant. Arch Fr Pediatr 1983;40:689-95.

7 Bancaud J. Kojewnikow's syndrome (epilepsia partialis continua) in children. In: Roger J, Dravet C, Bureau M Dreifuss FE, Wolf P, eds. Epileptic syndromes in infancy, childhood and adolescence. London: John Libbey Eurotext, 1985:286-98.

8 Gray F, Serdaru M, Baron H, Daumas-Duport C, Loron P, Sauron B, Poirier J. Chronic localised encephaliti (Rasmussen's) in an adult with epilepsia partialis continua. I Neurol Neurosurg Psychiatry 1987;50:747-51.

9 Piatt JH Jr, Hwang PA, Armstrong DC, Becker LE, Hoffman HJ. Chronic focal encephalitis (Rasmussen syndrome): Six cases. Epilepsia 1988;29:268-79.

10 Oguni H, Andermann F, Rasmussen TB. The natural history of the syndrome of chronic encephalitis and epilepsy: a study of the MNI series of forty eight cases. In: Andermann F, ed. Chronic encephalitis and epilepsy: Rasmussen syndrome. Boston: Butterworthepilepsy: Rasmussen synd

11 So $N$, Gloor P. Electroencephalographic and electrocorticographic findings in chronic encephalitis of Rasmussen type. In: Andermann F, ed. Chronic encephalitis and epilepsy: Rasmussen syndrome. Boston Butterworth-Heinemann, 1991:37-45.

12 Dubeau F, Sherwin AL. Pharmacologic principles in the management of chronic focal encephalitis. In Andermann F, ed. Chronic encephalitis and epilepsy: Rasmussen syndrome. Boston: ButterworthHeinemann, 1991:179-92.

13 Olivier A. Cortical resection for diagnosis and treatment of seizures due to chronic encephalitis. In: Andermann F, ed. Chronic encephalitis and epilepsy: Rasmussen syndrome. Boston: Butterworth-Heinemann, 1991:205-11.

14 Spencer SS, Spencer DD. Corpus callosotomy in chronic encephalitis. In: Andermann F, ed. Chronic encephalitis ancephalitis. In: Andermann F, ed. Chronic encephalitis worth-Heinemann, 1991:213-8.

15 Morrell F, Whisler WW, Smith MC. Multiple subpia transection in Rasmussen's encephalitis. In: Andermann F, ed. Chronic encephalitis and epilepsy: Rasmussen syndrome. Boston: Butterworth-Heinemann, 1991:219-33.

16 Villemure JG, Andermann F, Rasmussen T. Hemispherectomy for the treatment of epilepsy due to chronic encephalitis. In: Andermann F, ed. Chronic encephalitis and epilepsy: Rasmussen syndrome. Boston Butterworth-Heinemann, 1991:235-41.

17 Walsh P. Treatment of Rasmussen's syndrome with intravenous gammaglobulin. In: Andermann F, ed. Chronic encephalitis and epilepsy: Rasmussen syndrome. Boston: Butterworth-Heinemann, 1991:204-4.

18 Dulac O, Robain O, Chiron C, et al. High dose steroid treatment of epilepsia partialis continua due to focal encephalitis. In: Andermann F, ed. Chronic encephalitis and epilepsy: Rasmussen syndrome. Boston: Butterworthand epilepsy: Rasmussen syndr

19 Delalande O, Pinard JM, Basdevant C, Gauthe M, Plouin P, Dulac O. Hemispherotomy: a new procedure for central disconnection [abstract]. Epilepsia 1992;33 (supp 3):99.

20 Vining EPG, Freeman JM, Brandt J, Carson BS, Uematsu S. Progressive unilateral encephalopathy of childhood (Rasmussen's syndrome): a reappraisal. Epilepsia 1993; 34:639-50.

21 Gupta PC, Rapin I, Houroupian DS, Roy S, Llena J, Tandon PN. Smoldering encephalitis in children. Neuropediatrics 1984;15:191-7.

22 Robitaille Y. Neuropathologic Aspects of Chronic Encephalitis. In Andermann F, ed. Chronic encephalitis and epilepsy: Rasmussen syndrome. Boston: Butterworthand epilepsy: Rasmussen sym

23 Mizuno Y, Chou SM, Estes MI. Chronic localized encephalitis (Rasmussen's) with focal cerebral seizures. encephalitis (Rasmussen's) with foca

24 Andermann F, Rasmussen TB. Chronic encephalitis and epilepsy: an overview. In: Andermann F, ed. Chronic encephalitis and epilepsy: Rasmussen syndrome. Boston Butterworth-Heinemann, 1991:283-88.

25 Zemskaya AG, Yatsuk SL, Samoilov VI. Intractable or partial epilepsy of infectious or inflammatory etiology: recent surgical experience in the USSR. In: Andermann F, ed. Chronic encephalitis and epilepsy: Rasmussen syndrome. Boston: Butterworth-Heinemann, 1991:271-9.

26 Power C, Poland SD, Blume HD, Girvin JP, Rice GPA Cytomegalovirus and Rasmussen's encephalitis. Lancet 1990;ii:1282-4.

27 Walter GF, Renella RR. Epstein-Barr virus in brain and Rasmussen's encephalitis, Lancet 1989;i:279-80.

28 Harvey AS, Andermann F, Hopkins IJ, Kirkham TH, Berkovic SF. Chronic encephalitis (Rasmussen's syndrome) and ipsilateral uveitis. Ann Neurol 1992; 32:826-9.

29 Andrews JM, Thompson JA, Pyser TJ, Walker ML Hammond ME. Chronic encephalitis, epilepsy, and cerebrovascular immune complex deposits. Ann Neurol cerebrovascular

30 Beer S, Kesselring J. Steroidtherapie bei Multipler Sklerosis. Schweiz Med Wochenschr 1991;121:961-9. 
31 Durelli L, Cocito D, Riccio A, et al. High dose intravenous methylprednisolone in the treatment of multiple sclerosis: clinical-immunologic correlations. Neurology 1986; $36: 238-43$.

32 Chong G, Mourad G, Levy P, Nedelec G, Guidicelli C, Mion C. Chorio-retinite à cytomegalovirus: complication rare et grave chez le transplanté rénal. Intérêt du diagnostic précoce et du traitement prolongé par le DHPG. Néphrologie 1990;11:255-8.

33 Tokunaga $N$, Ichikawa $Y$, Kuboshiro $M$, Higashi $T$, Fujino K, Kaji M. A case of pulmonary tuberculosis associated with adult respiratory distress syndrome during corticosteroid treatment of rheumatoid arthritis. Kekkaku 1990;65:539-43.

34 Walsh DA, Durance RA. Fatal acute pyelonephritis following pulsed methylprednisolone for rheumatoid arthritis. Ann Rheum Dis 1990;49:955-6.

35 Chikanza C, Fernandes L. Arrhythmia after pulse methylprednisolone therapy. Br f Rheumatol 1991;30:392-3.

36 Tvede N, Nielsen LP, Andersen V. Bradycardia after highdose intravenous methylprednisolone therapy. Scand $\mathcal{f}$ Rheumatol 1986;15:302-4

37 Jones JG. Avascular necrosis and pulsed methylprednisolone in RA. Br F Rheumatol 1988;27:497-8.

38 Gardiner PV, Griffiths ID. Sudden death after treatmen with pulsed methylprednisolone. $B M \mathcal{F}$ 1990;300:125

39 Lyons PR, Newman PK, Saunders M Methylprednisolone therapy in multiple sclerosis: a profile of adverse effects. F Neurol Neurosurg Psychiatry 1988 51:285-7.

40 Williams IA, Mitchell AD, Rothman W, Tallett $P$,
Williams K, Pitt P. Survey of the long term incidence of osteonecrosis of the hip and adverse medical events in rheumatoid arthritis after high dose intravenous methylprednisolone. Ann Rheum Dis 1988;47:930-3.

41 Snead III OC, Benton JW, Myers GJ. ACTH and prednisone in childhood seizure disorders. Neurology 1983;33:966-70.

42 Dorfman A, Apter NS, Smull K, Bergenstal DM, Richter RB. Status epilepticus coincident with use of pituitary adrenocorticotrophin hormone. $\mathscr{f} A M A$ 1951;146:25-7.

43 Hasaerts D, Dulac O. Traitement par hydrocortisone des epilepsies genéralisées secondaries du grand enfant. Arch Fr Pediatr 1989;46:635-9.

44 Stephens EHM, Noad KV. Status epilepticus occurring during cortisone therapy. Med ₹ Aust 1951;38:334-5.

45 Conford E, Oldendorf W. Epilepsy and blood brain barrier. In: Delgado-Escueta A, Ward A, Woodbury D, Porter R. eds. Advances in neurology: basic mechanisms of Portepsies. New York: Raven Press, 1986:787-812.

46 Sokrab T-E O, Kalimo H, Johansson BB. Parenchymal changes related to plasma protein extravasation in experchanges related to plasma protein extravas

47 Siemes H, Siegert M, Aksu F, Emrich R, Hanefeld F, Scheffner D. CSF protein profile in infantile spasms. Influence of etiology and ACTH or dexamethasone treatment. Epilepsia 1984;3:368-76.

48 Miller DH, Thompson AJ, Morrissey SP, et al. High dose steroids in acute relapses of multiple sclerosis: MRI evidence for possible mechanisms of therapeutic effect. f Neurol Neurosurg Psychiatry 1992;55:450-3.

\section{NEUROLOGICAL STAMP}

\section{Pierre Joseph Pelletier (1788-1842) and Jean Bienaime Caventou (1795-1887)}

The French chemist Pelletier's major work was the investigation of drugs, which he began in 1809. Later he worked with the pharmacist and organic chemist Caventou. Their collaborative studies, which began in 1817 , included the isolation of strychnine from nux vomica (1818), caffeine (1821), and quinine from cinchona bark (1820). It was not until 1936 that Wolff reported on the effectiveness of quinine in relieving myotonia. Later, in 1955, Geschwind and Simpson noted the "quininelike" action of procainamide on repetitive firing of cardiac muscle and suggested that it might be effective in combating myotonia.

Caventou, an expert in toxicology (Professor of Toxicology at the Ecole de Pharmacie (1835-1860)), also reported on cases of arsenical poisoning. Philatelically both were honoured by France in 1970 to commemorate the 150th anniversary of the discovery of quinine (Stanley Gibbons 1870, Scott 1268). Pelletier and Caventou are regarded as the founders of alkaloid chemistry. Caventou's early successes were not repeated in later life. After Pelletier's death in 1842 Caventou published nothing further.

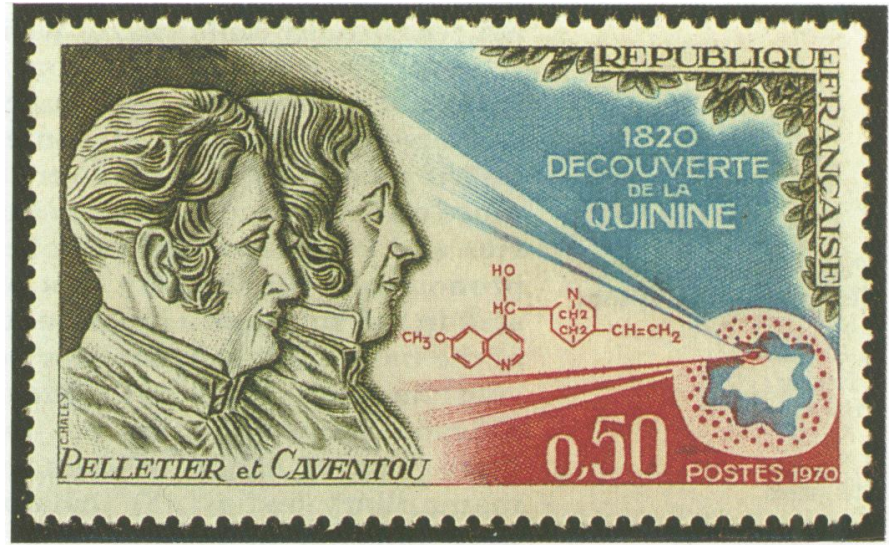

